\title{
Trustees, tribunals and taxes: creativity in Victorian law
}

\author{
by Chantal Stebbings
} This article is taken from a lecture given to the Society for Advanced Legal Studies on
February 19, 2007 .

\section{INTRODUCTION}

$\mathrm{I}$ t is well known that the contribution of the Victorians to so many aspects of modern civilisation is astonishing in its breadth, boldness and scale. The great technological and architectural achievements of the Victorians are still very visible today, and their magnitude is striking even now. But the creativity so marked in these fields is not necessarily as evident in law. And yet the study of almost any branch of English law shows that the Victorians were as active and influential in moulding the law and establishing enduring legal institutions as they were in other areas of national activity. In terms of reforming the old substantive law they did a great deal - they reduced the number of capital crimes dramatically; abolished imprisonment for debt; legislated to protect vulnerable groups such as dissenters, children and the mentally ill; gave married women property and other legal rights; founded modern employment law; legislated to protect animals, and much more. They were just as active in the procedure of the law as in its substance -they completely restructured the entire system of courts in this country with their passion for classification, hierarchy and uniformity, they abolished the many courts of special jurisdiction, removed archaic procedures and introduced the Supreme Court of Judicature. The sheer bulk, breadth and pace of Victorian legislation are undeniable. The question, however, is how novel, how creative, the Victorians were in law, and whether there were any reforms which matched the undoubted innovative genius of Brunel, Bazalgette and Stephenson, the groundbreaking perception of Darwin, the creative brilliance of Dickens and so many others in so many different fields.

\section{A NEW INDUSTRIAL SOCIETY}

Victoria's reign opened in 1837 at the height of an unprecedented challenge to the established legal order to meet the demands of a new and dynamic industrial economy that had transformed the country. Before 1800, England was essentially an agricultural country, and most manufacturing industry was domestic, local and smallscale, using limited forms of power. By 1837 , however, the essentials of an industrial revolution were in place - the developments in technology allowing steam power to replace natural power, the production of quality iron and the mechanisation of industry, the developments in communications, a growth in overseas trade and the opening of new markets in America, India and the far East, and the development of London as the financial and commercial centre of the world - all this had already happened when Victoria came to the throne. The coal and iron industries, cotton factories and railways then developed rapidly. In less than 100 years, society had been transformed to become industrial dominated by mass production and heavy industry, with factories, machines and labour concentrated in the towns.

Industrialisation and the trebling of the population in less than a century brought its own problems. The growth of towns brought problems of housing, sanitation, water supply and epidemic while the increase in factories and mines raised issues of health and safety, of the employment of women and children, and of education. Similarly the growth of large-scale commerce and industry brought with it unprecedented capital demands for plant, machinery and, in the case of railways, land. The problems of food supply, on the other hand, were less obvious. There were deficiencies in the system of land tenure, land law and taxation which made the country less able to support its rapidly growing population. Then there came issues emerging from the progress in technology, such as the railways, which raised questions of public safety and the compulsory purchase of land. Finally, the pervasive increased pace of commercial enterprise raised problems of all kinds, notably a law of property based entirely on landownership and a rudimentary law of commercial association.

\section{THE CHALLENGES TO THE LAW}

The challenges to established legal institutions and processes were many and various, and nearly all branches of the law had to respond to ensure they were suited to the new conditions. The extent to which the Victorians were 
creative in their response can be illustrated by examining three particular areas - trustees, tribunals and taxes. They all involved responses to major challenges springing from this economic and social transformation, responses which left an enduring legal legacy. Not only does each reflect a different aspect of the law, with trusteeship concerning private affairs, tribunals the legal process, and taxation public affairs, but between them they illustrate the different degrees of legislative, judicial, professional and bureaucratic involvement in the reform.

\section{The trustee}

The trust is a familiar institution today, affecting many aspects of modern life including arrangements created to minimise taxation, to establish pensions and investments and facilitate charitable giving. But it was an institution that profoundly affected the private lives of individuals in the Victorian period, and one that they succeeded in moulding to give it its modern form. When the Victorians encountered the trust it was an institution that was apparently fixed in its traditional $18^{\text {th }}$ century character as a tool for the landed aristocracy to preserve their estates and wealth in their families through the generations. The traditional ethos of the trustee was that it was legally a matter for his conscience. It was undertaken personally, and was usually unpaid. Trustees, who were friends or relatives of the same social class, men of integrity, morality and an understanding of the family and its station in life, took on a trust out of loyalty and affection. They would feel morally bound to do so.

The family was of immense importance to the Victorians. It was the institution at the centre of their lives, and the head of the family was responsible for his wife and his usually numerous children. This was at a time where there was no welfare state, and where illness and epidemic made life itself very uncertain. It was common for a father to be left to bring up his family alone, since so many women died in childbirth, and it was equally common for children to be left orphaned. Children and women had to be provided for, the latter because married women were entirely dependent on their husbands since they were incapable of holding property at Common Law, and single women, whether unmarried or widowed, had very few ways open to them of earning a living.

Victorians of the middle classes had no great landed estates to deal with, but had small, or not so small, fortunes which they wanted to use above all to provide for their families. Their desire was not the preservation of a specific landed estate for future generations as it had been in the $18^{\text {th }}$ century, but rather the preservation and growth of a fund for the support of the next immediate generation or the support of dependants in the event of an early death. The trust as a legal institution met the practical demands of the new dynamic commercial Victorian society with little alteration, and it was welcomed with enthusiasm. The trust concept alone, however, was of limited assistance to achieve their aims, because it depended in practical terms on the availability of able and willing trustees to administer it, to make the investments, to distribute income, to look after the beneficiaries and make all the decisions. And the rules of trusteeship, namely the law of trust administration, were quite inadequate.

The problem was that trusteeship was increasingly unattractive. The new commercial conditions in which trustees had to operate meant it was now twice as hard to administer a trust. The scale of the burden had changed, and the powers which the law gave them to administer their trusts - remuneration, investment, delegation - were far too limited. For example, there now existed many new investment opportunities - joint stock companies and banks, the new public utilities, canal and railway companies, and the huge opportunities for investment in an ever-growing Empire overseas. As a result merely selecting the correct investment had become much more difficult. To make a correct investment choice among the hundreds of different railway companies and their shares and debentures, or which government securities to buy, required real knowledge of the industries themselves and of the commercial scene in general. Once purchased, investments needed to be managed - watched and changed continuously, with all the accounts, record-keeping and paper-work that that involved, to make sure the fund was preserved.

Trusteeship was not only more complex and burdensome, it was perceived as utterly thankless, and was not remunerated. Above all, however, it was risky. The law as to the liability of trustees was striking in its severity. Early equity adopted a view of extreme paternalism, and saw the beneficiary as a victim ripe for exploitation. The courts felt they had to be supremely vigilant, for if trustees were given an inch, they would take a mile. Accordingly errant trustees had to be dealt with swiftly and severely to serve as an example to others. A trustee would be personally liable to his last penny to make good any loss arising from any simple mistake or error of judgment which he made, however honest or well-intentioned he had been. And now, in the new commercial conditions, it was much easier to make such a mistake. The result was that few were prepared to act as trustees; it was simply too heavy a responsibility.

By the end of the nineteenth century the burden of work and worry on lay trustees was intolerable, and there was a severe recruitment problem. The traditional rules of trust administration were revealed as inadequate. Trusteeship, founded in moral obligation and in the context of landed estates, now had to operate in a largely urban and industrial society where wealth was expressed not so much in land but in money, shares and debentures.

The Victorians met this challenge by adapting trusteeship to suit the needs of the new and powerful middle classes operating in the new conditions of the 
nineteenth century who wanted to use the trust. In reforming the law, judges did relatively little. Most judges were conservative: they did not want trustees to be paid, to delegate their tasks to accountants or surveyors unless absolutely necessary, and on the whole they wanted them to remain liable for any breach of trust however honest the mistake. This was because they staunchly maintained the traditional view of trusteeship as a personal duty on the trustee, an office of confidence, a moral obligation. Similarly, the reforms that came from Parliament were piecemeal and minor. Even the extension of investment powers promoted by the more progressive lawyers was grudgingly given and strictly limited. In fact, the judges and legislators created a comprehensive default law of trust administration that adhered to the orthodox view of trusteeship and as such failed to meet the new conditions. The legal profession, on the other hand, was active in this respect and constituted the motive force in the reform of the law of trusteeship.

Professional lawyers achieved two important changes. The first was in relation to express powers in trust instruments. In the face of an inadequate default law, trustees themselves realised they needed expert help, namely professional advisers to advise and not just to follow instructions. These advisers - solicitors, barristers and conveyancing counsel - drafted specific codes of law for each trust. They included provisions to allow trustees to invest widely, to delegate and to be protected from liability for breach by indemnity clauses. These express powers were a reflection of practice, of what settlors thought was necessary and sensible. Solicitors conceived and suggested the powers, which would then be enforced by the courts, and as they became common, could be accepted as standard form and even eventually implied by statute in all trust deeds. In this way the legal profession had a very real influence over the content and form of law, and it was largely through their efforts that it was kept up to date. The second change was the professionalisation of trusteeship. As solicitors became more involved in trusteeship, and as it became an increasingly difficult office, so they began themselves to be appointed trustees. This professionalisation of trusteeship considerably weakened the traditional personal nexus between trustee and settlor.

As a result of these changes the typical trustee at the end of the Victorian period was quite different from that of the beginning of the reign. He had become the manager of a fund, of a portfolio of investments, rather than the guardian of a family's landed estate. Trusteeship was no longer a matter of personal confidence and moral obligation, but a matter of expertise and ability to pay. It was a skilled occupation undertaken for profit, a matter of business. The trustee had been transformed from an amateur to a professional, from a layman to a businessman.

\section{Tribunals}

The tribunal, like the trust, is a very familiar institution today. An individual citizen's personal contact with a formal adjudication process is far more likely to be in the context of an administrative tribunal than of a court of law. Tribunals operate in a wide range of aspects of everyday life - social security benefits, health, education, tax, agriculture, criminal injuries compensation, immigration and asylum, and rents are just some examples - hearing and determining appeals by individuals aggrieved by an administrative decision taken by an organ of the state. This legal institution, now so immensely important and generally perceived as a very modern idea, was the creation of the Victorians.

The need for this kind of body emerged in the wake of the social welfare problems arising out of industrialisation and urbanisation. The need for reform was undeniable, and new laws were passed to regulate working hours and conditions in factories and mines, to guarantee a safe and convenient railway system, to ensure that no land was wasted in terms of agricultural production, to prevent epidemic, to educate children and much else besides. Such was the magnitude of the task that only central government could provide the necessary degree of initiative, authority and control to implement the reforms uniformly and effectively. What was clear, however, was that in the course of administering these new laws, disputes would inevitably arise between the government authority and the public. After all, the government was having to pass legislation which was necessary but usually unpopular, because more often than not it infringed the private property rights of a section of the public, or their privacy, or their vested interests. The fact it was being done by central government made it worse, because the Victorians disliked bureaucracy and state intervention. The need, therefore, was to provide for the determination of appeals by individuals aggrieved by a decision of an administrative officer, and the challenge was to find a way of doing so which had public support, for popular acceptance was essential to government policy.

The Victorian legislators could have simply given the business to the regular courts of law, and in many ways that was the obvious solution. The courts were familiar, their procedures were ancient, with a long tradition of built-in safeguards and the judges had authority and respect. There were, however, problems with that solution. The kind of disputes which the new legislation gave rise to were small questions of fact which were often quite technical in nature. They were, for example, disputes as to where the boundaries of land were, or where a railway station should be built where it was shared by two companies, whether rates were fair, whether a tax assessment was correct. As such they demanded a specialist knowledge. In order to safeguard public safety on the railway and to ensure the system worked efficiently, for instance, both engineering skill and knowledge of railway management were required. The judges in the law courts, while they were expert in the 
law and the handling of evidence, were not experts in areas such as railway engineering, or land valuation, or agricultural practices or taxation, and neither were they willing to adjudicate small administrative disputes.

There were other considerations. Any process also had to be quick not only to retain the support of the public, but also because the various problems which the legislation sought to remedy were urgent and the implementation of government policy could not be held up. The Victorian courts of law were hardly expeditious. Indeed they were notoriously slow, technical and formal, and the system of precedent rendered them inflexible. The opening of Bleak House was set in a cloying fog that symbolised the fog of the Court of Chancery, and Jarndyce $v$ Jarndyce remains one of the most vivid and accurate portrayals of the interminable nature of legal proceedings in the early Victorian courts. The common law courts were little better. The state of the courts made the public afraid of going to law. They feared its delay and the tendency to get sucked into its process. Above all, they feared its expense.

It was well known that expense was the result of the involvement of lawyers. To have swift, cheap and knowledgeable justice with public support, professional lawyers had to be avoided. The solution was to make the procedures so simple and informal that legal representation was not necessary, and to make them local, rather than making the parties go to London, with all their witnesses, and lodge there while the case ran its course. It was clear that in this respect the regular courts could not be used, since they all required lawyers. Even the Justices of the Peace, who were the obvious choice, were not suitable. They were too conservative, too independent and too busy and, like the judges, they lacked specialist knowledge.

The legislators, therefore, knew exactly what they wanted and what they needed and, more importantly, what they did not want. Not only did they have to select an organ to administer the new legal regimes and resolve disputes, they had to construct new jurisdictions, procedures, constitutions and sufficient safeguards to ensure acceptable standards of justice.

The solution was to create commissions to implement the legislation and to give them the additional task of deciding any disputes that might arise. These commissions were composed not of judges but of laymen with specialist expertise in the area in question. Their procedures were simple and informal, with letters and meetings replacing writs and pleadings, and which accordingly rarely needed lawyers at all. And since the Victorians were ideologically opposed to compulsion, the procedures were based primarily on agreement, with compulsion as a last resort. Within this framework they tried endless combinations and considered many different types of dispute resolution. Lay expert judges, lay expert assessors, professional judges, part time judges, legal experts who weren't judges, costs, no costs, appeals, no appeals, limited appeals, legal representation by barristers, solicitors, parliamentary agents or even none at all, combinations of formal adjudication with arbitration or conciliation, were all considered and some employed. The outcome was a number of individual tribunals, all ad hoc, with little unifying principle or coherence as a class, but immensely effective. Above all, these tribunals were accessible to the people who needed them. They were cheap, simple, fast and local, all of which features are very modern notions of access to justice.

Whereas in the case of trusteeship the motive force in reform had been the legal profession, in the case of tribunals it was the legislators themselves.

\section{Taxes}

The challenge to taxation at the beginning of the Victorian period was that of an empty Treasury. This was due largely due to the debt resulting from the French Wars earlier in the century, high navy and army costs, the earlier remission of a number of taxes to promote Whig free trade and the pressure for more. The government had not only to secure new sources of public revenue, but equally to ensure its steady and consistent flow to government to sustain the rapid and widespread reforms of the period and meet the increased expenditure of a developing bureaucratic state. The problem was not one of lack of taxes. Even though the income tax had been suspended since 1816, Sir Robert Peel understood that this would provide the fiscal solution. The reintroduction of the tax would enable him to raise money and give him the political space to reform the customs and excise and promote his principles of free trade. The real problem was one of machinery. Efficient administration was the key to sound and effective taxation. It was crucial because the consistency of revenue was as important as the yield. The government wanted the tax administered efficiently, promptly and uniformly, and the existing machinery did not achieve this. It meant that the government could not effectively tap the new and great wealth of the industrial revolution, namely commercial income.

The existing system of tax administration for income tax was a local one. Independent lay commissioners received the tax returns and assessed individuals to tax in their localities. They heard and determined appeals against assessments and they appointed collectors to collect the tax. Central government in the form of the Inland Revenue had only a supervisory role. The officer of central government could inspect the returns and object to them if he chose, but could do nothing more. The ultimate legal authority and control lay in the local commissioners. While this local system had evolved as the principal safeguard for the taxpayer, holding the balance between him and the Crown to ensure taxation was not abused, it was inadequate in the new conditions of the nineteenth century and prevented the full taxation of the new wealth. 
First, the local commissioners were local laymen, often retired merchants or bankers in the cities, or doctors and clergymen in the country. They were drawn from the Justices of the Peace, though often had a greater commercial expertise and interest. As commerce increased in both scale and complexity and the country became wealthier, so the income tax followed suit. The quantity of work grew, and the unpaid, part-time, amateur commissioners, with other demands on their time and energies, could not or would not devote sufficient time to the demands of their office. There was also a problem of expertise. The commissioners had no formal training, only a general knowledge of business and of local economic conditions. While this had been adequate in the eighteenth century, it could not meet the demands of a rapidly expanding commercial context. Tax assessment had become technical and complex, requiring a knowledge of tax law and practice and accountancy which most commissioners did not possess. Indeed, more often than not they relied on a general impression of the income of taxpayers, gleaned from gossip and outward appearances to arrive at the assessment to tax. Secondly, there was the very real problem of disclosure. The administration of income tax demanded a close investigation into the private financial affairs of individuals. All taxpayers, but especially commercial taxpayers, were reluctant to be assessed by local men who were often their competitors in trade for fear of commercial espionage or other misuse, fear of its effect on their credit, or simply a desire for the preservation of secrecy in personal financial affairs. It was clear that localism as the basis of tax administration was no longer appropriate or effective, and that it had to be reformed.

The need for increased public revenue was directly addressed by the reintroduction, in 1842, of the income tax of 1799. The reform of the machinery of income taxation was far more challenging. This was because there were very powerful ideological and practical reasons for keeping the traditional local system, which governments had, for political reasons, to respect. The English had always valued local self-government. As its institutions were perceived as enshrining their very liberties, it was an attachment that made the adoption of a locally based system of tax administration a political necessity. To use a traditional system which was familiar and understood by all taxpayers, and which satisfied their desire for local control, was also a powerful pacifier in view of widespread concern and distrust of the new tax. It was also the cheapest option, a point which held considerable appeal for Victorian legislators. While politically, therefore, governments needed localism, fiscally they knew that it was not efficient. Consequently successive governments set about increasing the role of the executive in tax administration.

First, Peel addressed the problem of the failure fully to tax commercial income by introducing a new method of assessment. He gave extended powers to the Special
Commissioners of Income Tax, a tribunal of salaried civil servants, to assess commercial income and hear appeals against such assessments if the taxpayer chose. It was to reassure the commercial community that their income could be assessed by a body quite independent from their competitors in trade, and assessed both secretly and expertly. Secondly, the Inland Revenue tried to remove the right of the local commissioners to appoint their own officials. There was an unrelenting and partly successful movement to allow collectors to be appointed by the revenue. This was optional, in that the revenue only appointed a collector when the commissioners failed to do so, but attempts continued to make it compulsory. And thirdly, there were instances, particularly in Scotland, where the assessing power of the local commissioners was given to officials of the Inland Revenue.

These three reforms were overt efforts by the revenue department to acquire the powers of the local administrative bodies. In increasing the control of central government, they undermined the local system of tax administration. There was also, however, an insidious undermining of local administration through the growth of the expertise of the surveyor, the officer of central government. As tax law and practice became more complex and technical, he came to dominate the local commissioners. He was expert, articulate and informed and part-time, amateur commissioners were no match for him. The movement continued by which ultimately the local commissioners were directly and indirectly stripped of all their administrative powers and their own officials abolished. In practice these changes and reforms undermined local tax administration almost entirely. In theory, however, it was largely untouched. It was an instance where there was an almost complete dislocation between theory and practice, since the law retained the local commissioners as the supreme authority, while practice made the government surveyor the pivotal figure.

\section{LEGAL CREATIVITY}

In each of the three fields of trusteeship, tribunals and taxes the Victorians effected a major reform of the law. The trustee was transformed from an office of moral obligation to a commercial institution, and that transformation had been driven by the legal profession; the tribunal, a statutory organ of government with administrative and judicial powers, had been created as a new institution, as a result of the work of legislators; and a system of local tax administration had been adapted to suit a new fiscal scene. A new system had been brought into existence largely by the force of a new bureaucracy. In assessing the degree of legal creativity in these reforms, it is clear that in one sense they were not novel at all. None introduced any entirely new concept into the law.

With respect to the trustee, the concept of the trust was left untouched in its essentials, and the judiciary and Parliament left the principles of trust administration 
fundamentally the same. In taxation they reintroduced a tax known to English law since 1799, and adopted its traditional and much older machinery wholesale and theoretically unchanged. Even in the creation of a novel institution, the tribunal, the component parts were not new. The idea of using laymen rather than judges was well known to the law, in the form of Justices of the Peace, juries and arbitrators. Neither was the idea of using specialists as adjudicators new, as courts of special jurisdiction such as the various commercial and borough courts had existed for hundreds of years.

The notion of a simple informal procedure based on consensus was known in arbitration, and the fundamentals of the procedures ensuring a fair hearing were part of the established courts of law.

Similarly having both administrative and judicial powers in one body was not peculiar to the statutory tribunals, since this too was known to the regular legal system. Justices of the Peace were the prime example. It is clear that the courts of law, other orthodox legal processes and general legal values, all commonplace in English legal and public life, provided the legal foundations of the tribunal. In that sense the creation of the tribunals was not novel, not a newly conceived method of dispute-resolution.

It is suggested, nevertheless, that the Victorian legislators were both creative and innovative in their legal reforms. Their originality lay in this very use of existing legal concepts, in the recasting of established judicial notions. They were prepared to deconstruct legal institutions and practices which had been established for hundreds of years and which had been regarded as indivisible, then to extract from each those features they regarded as serving their purpose, and finally to reconstruct them in the form they needed. Their originality, creativity and indeed their genius, lay in this deconstruction and reconstruction, in a willingness to split these bundles of powers and duties which had traditionally been regarded as capable of existence only in one, and their selectivity once this had been achieved. It lay in the fact that the Victorian legislators did not adopt any of these established concepts wholesale. Instead they selected the elements they wanted, adapted and refined them to suit their particular needs. They were prepared to enhance some features and depress others, and finally to recast them to form new and original institutions. In this they showed a remarkable openmindedness and a readiness to be innovative, to improvise and to compromise. They were not afraid of looking outside the legal institutions they were reforming, and they were not constrained by established forms and techniques.

With respect to the trustee they were prepared to deconstruct traditional trusteeship, to weaken its roots in conscience and remove the trappings of this underpinning of moral obligation. The moral dimension of trusteeship was no minor element, having characterised trusteeship for hundreds of years. It was done by the legal profession introducing new powers into trust deeds which sought to allow remuneration, more delegation and wider investments, and to limit liability. In short, to insert powers which unambiguously undermined the moral basis. It was the same with the professionalisation of trusteeship. This clearly went against the whole tradition of the trust as a personal relationship, and reduced its administration to a mere trade, a commercial, managerial office. Again, the Victorian legal profession led the changes by drafting trust deeds boldly and in an imaginative way and by their persistence. With tribunals, legislators had the imagination to shed excessive formality and technicality to achieve the cheapness and speed required. Court rules of procedure were not adopted wholesale, and certain elements that were not necessary to ensure a fair and disciplined hearing, and which served only to lengthen the process, were discarded. They drew on the features of the regular courts, of arbitration, of boards, of government departments, of juries, and of parliamentary private bill committees. They selected those features and techniques of established legal or quasi-legal institutions that suited its purpose and invented new processes if none existed.

The reform of tax administration reveals another kind of deconstruction, and one led by the increasingly powerful revenue organs of the executive. They took the established and pragmatic legal structure of central supervision and local administration, itself a compromise between the government's desire for control and uniformity, and a traditional local demand for self-government, and gradually changed the balance. They deconstructed localism and filled gaps with centralism, as alternatives (as with the Special Commissioners), or covertly (as in the increasing power of the Inspector), or expressly replacing it (as in the appointment of their own collectors). In this, and indeed in reintroducing income tax after a suspension of a quarter of a century, they showed real resourcefulness.

This imaginative and confident use of diverse established institutions or elements of them was characteristic of the age, and was particularly clear in the case of tribunals. The Victorian lawyers and legislators had a clear end in view, and used all the legal tools at their disposal. Deconstruction and reconstruction is one of their great achievements. It occurred in other fields, notably in the development of the incorporated company. In that case the law provided that if a body were incorporated, then it would acquire all the characteristics of corporateness. The features of perpetual succession, a common seal, a name, the ability to sue and be sued and, most importantly, limited liability, applied to every corporation. In moulding a company law to suit the new commercial age, however, the legislators did not want to go to that extent. Their approach, therefore, was to split the bundle of corporate privileges, select the ability to sue and be sued in one name, and give it to the large unincorporated associations which had evolved from partnerships. This did not incorporate them, but it gave them one of the privileges of 
incorporation. Legislators showed the same willingness to deconstruct legal corporateness in relation to limited liability. The business community wanted limited liability above all, but as it was believed to encourage fraud, legislators did not want to grant it freely and without restriction. When, therefore, the law eventually allowed business organisations to obtain corporate status easily and cheaply simply by registering themselves under an Act of Parliament, it was incorporation without limited liability: the legislature had removed that particular element from the corporate bundle and granted the rest. In fact limited liability was given to these companies just a few years later, but it was conspicuously missing when incorporation by registration was first introduced.

In this use of legal concepts the Victorians were not only imaginative and courageous in their construction and deconstruction of legal institutions and concepts. They were also prepared to extend accepted legal thinking, as when they integrated judicial and administrative functions in the tribunal in a way not seen in the jurisdiction of the Justices of the Peace. Again they were prepared to be, and knew they were being, experimental, for example by giving the implementation of the railway legislation to the specialised and independent Railway and Canal Commission in 1873, presided over by a High Court judge. They were prepared to keep trying new combinations of features as many times as was necessary. They were above all pragmatic. They had clear objectives and set out to achieve them in a practical workable way, and in this they were untroubled by underlying legal principle or by archaic form. Indeed they wanted to be rid of legal anachronisms and to reform the law by giving it the freedom to adapt to new conditions in the light of new values. They reacted to events and legislated as it became necessary, avoiding prescription and principle to ensure flexibility. They were realistic, and knew when an institution worked and when it did not. If it worked, as in the income tax, they did not feel the need to reform it. The prime example of their preference to be guided by pragmatism rather than theory is their creation of the bespoke tribunal and their development of tribunal procedures. They were prepared to have no consistency or common principles as long as they worked.

This pragmatic creativity was entirely Victorian. Their law was, in 1837, highly technical, slow, and often artificial, and not suited to a dynamic commercial society. The challenges facing the legal system demanded innovation and creation. They saw that these could be met with the legal tools at their disposal, and they had the imagination to exploit them to achieve their aims. Legal reform of this kind and on this scale was an expression of the great confidence the Victorians had in their ability to address the considerable challenges their age presented. It was that same robust confidence which moved the engineers, architects and scientists to their own achievements, and it was just as enduring.

\section{Professor Chantal Stebbings}

Professor of Law and Legal History in the University of Exeter; author of

The Private Trustee in Victorian England, (Cambridge University Press

2001) and Legal Foundations of Tribunals in Nineteenth Century

England, (Cambridge University Press 2006).

- The writer would like to thank the British Academy and the Leverhulme Trust for their support of various aspects of this work. 